\title{
NOTE
}

\section{Flavobacterium breve sp. nov., nom. rev.}

\author{
B. HOLMES AND R. J. OWEN \\ National Collection of Type Cultures, Central Public Health Laboratory, London NW9 5HT, United \\ Kingdom
}

The name Flavobacterium breve (Lustig) Bergey et al. 1923 was omitted from the Approved Lists of Bacterial Names. The taxon to which this name was applied is a distinct entity, and it can be differentiated from the other recognized species of Flavobacterium. Consequently, the name $F$. breve is revived for the same organism to which the name originally referred. The type strain of $F$. breve is NCTC 11099.

The name Flavobacterium breve (Lustig) Bergey et al. 1923, 116, does not appear on the Approved Lists of Bacterial Names (7), has had no standing in bacterial nomenclature since 1 January 1980 , and, according to Rule 24a of the International Code of Nomenclature of Bacteria (5), will not be added to the lists.

$F$. breve has been described in every edition of Bergey's Manual of Determinative Bacteriology to date. However, in the last edition of the Manual (8), some characteristics of the species were incorrect (4), and at that time only one reference strain of the species (ATCC 14234, isolated from fish) was available from culture collections. Subsequently, Holmes et al. (4) studied six additional clinical strains of the species. From their study they provided an emended description of the species, proposed NCTC 11099 as the neotype strain, and deposited three of their strains in a major culture collection (4). The taxonomic status of the species was further discussed in a Request for an Opinion to the Judicial Commission (2), in which it was proposed that $F$. breve should replace $F$. aquatile, the current type species of Flavobacterium. There is no uncertainty of the validity of the species to which the name $F$. breve has been applied. The name appears (see p. 576) in the first draft of the Approved Lists of Bacterial Names (1) and does not appear on the lists of nomina rejicienda. The purpose of this report is to revive the name $F$. breve in accordance with Rules 27 and 28a and Provisional Rule B2 of the International Code of Nomenclature of Bacteria (5).

The morphological and biochemical reaction patterns of strains of $F$. breve are remarkably uniform (4). F. breve is a gram-negative, nonmotile rod. Indole is produced, and among named
Flavobacterium species this character is otherwise confined to $F$. balustinum and $F$. meningosepticum. However, F. breve, unlike F. balustinum and the majority of $F$. meningosepticum strains, does not hydrolyze esculin and does not generally produce acid oxidatively from carbohydrates other than glucose and maltose. These characters distinguish $F$. breve from other recognized Flavobacterium species $(3,4)$. A study of the deoxyribonucleic acids of $F$. breve strains (6) showed that the species constitutes a relatively homogeneous taxon, all the strains of which are readily distinguishable from allied flavobacteria. The history of the species has been described elsewhere (4).

The type strain of $F$. breve is NCTC 11099 , and it has been described previously (4). The type strain is typical of the species both phenotypically and genotypically $(4,6)$ and was chosen for that reason.

\section{LITERATURE CITED}

1. Ad Hoc Committee of the Judicial Commission of the ICSB. 1976. First draft. Approved lists of bacterial names. Int. J. Syst. Bacteriol. 26:563-599.

2. Holmes, B., and R. J. Owen. 1979. Proposal that Flavobacterium breve be substituted as the type species of the genus in place of Flavobacterium aquatile and emended description of the genus Flavobacterium: status of the named species of Flavobacterium. Request for an opinion. Int. J. Syst. Bacteriol. 29:416-426.

3. Holmes, B., R. J. Owen, and R. E. Weaver. 1981. Flavobacterium multivorum, a new species isolated from human clinical specimens and previously known as group IIk, biotype 2. Int. J. Syst. Bacteriol. 31:21-34.

4. Holmes, B., J. J. S. Snell, and S. P. Lapage. 1978. Revised description, from clinical strains, of Flavobacterium breve (Lustig) Bergey et al. 1923 and proposal of the neotype strain. Int. J. Syst. Bacteriol. 28:201-208.

5. Lapage, S. P., P. H. A. Sneath, E. F. Lessel, V. B. D. Skerman, H. P. R. Seeliger, and W. A. Clark (ed.). 1975. International code of nomenclature of bacteria (1975 revision). 
American Society for Microbiology, Washington, D.C

6. Owen, R. J., and B. Holmes. 1980. Differentiation between strains of Flavobacterium breve and allied bacteria by comparisons of deoxyribonucleic acids. Curr. Microbiol. 4:7-11.

7. Skerman, V. B. D., V. McGowan, and P. H. A. Sneath (ed.). 1980. Approved lists of bacterial names. Int. J. Syst. Bacteriol. 30:225-420.

8. Weeks, O. B. 1974. Genus Flavobacterium Bergey et al., 1923, p. 357. In R. E. Buchanan and N. E. Gibbons (ed.), Bergey's manual of determinative bacteriology, 8 th ed. The Williams \& Wilkins Co., Baltimore. 